\title{
Problemy związane z tzw. konstrukcją ciągłości przestępstwa w odniesieniu do instytucji prawa karnego procesowego - res iudicata oraz zakazu ne bis in idem
}

\begin{abstract}
Przemysław Krawczyk discusses the impact of institutions related to the continuity of a crime on the substantive validity of judgments in criminal cases and the ne bis in idem prohibition that flows from it. The study presents the views of doctrine and judicature which treat the scope of the validity of substantive judgment in relation to conduct (acts) committed in the conditions of continuity. It should be noted at the outset that positions on this issue tend to be diametrically different. Moreover, Krawczyk points out how important it is to set temporal limits to the continuity of an offence. This issue is of considerable importance from the point of view of the substantive validity of a ruling issued in a criminal trial, because incorrect or insufficiently precise delimitation of these limits may result in a violation of some fundamental principles of criminal law, both substantive and procedural.
\end{abstract}

Keywords: res iudicata, ne bis in idem, continuous crime, a series of crimes, substantive validity of judgement, jurisprudence

\section{Wstęp}

Problematyka ciągłości przestępstwa już od wielu lat jest osią sporu zarówno $\mathrm{w}$ doktrynie, jak i w praktyce prawa karnego sensu largo. Wiąże się to nie tylko z rozumieniem ciągłości jako takiej, ale przede wszystkim z wyznaczeniem granic samego czynu. Szczegółowe omówienie kwestii z tego zakresu, m.in. wyznaczania tzw. granic czynu, a także tożsamości czynu, przekracza ramy niniejszego opracowa- 
nia ${ }^{1}$. Wobec tego Autor pozwoli sobie tylko nadmienić, że określenie, co właściwie czynem jest na gruncie prawa karnego, a co nie, do dziś nie stanowi przedmiotu powszechnej zgody. Nie sposób jednak przejść obojętnie obok poglądu Mariana Cieślaka, skądinąd słusznego, który przed laty pisał: „[...] w rzeczywistości obiektywnej nie ma czynów w postaci jakiś odrębnych, oddzielonych od siebie aktów. Istnieją tylko tak czy inaczej zachowujący się ludzie, i to ich zachowanie się, będące przecież wyrazem ich nieprzerwanej egzystencji, jest pewną ciągłością, złożoną z najróżniejszych zlewających się ze sobą przejawów aktywności i bierności (»działań « i »zaniechań«). W tej ciągłości, którą można przyrównać do rzeki lub taśmy filmowej, dopiero obserwator (a może być nim nawet sam podmiot zachowania) wyróżnia interesujące go fragmenty (wycinki), tak jakby wycinał klatki w taśmie filmowej, i nazywa je czynami"2.

W świetle wspomnianego zagadnienia, a także tematyki opracowania, wypada zauważyć, że odnalezienie desygnatów pojęcia czynu jest niezbędne do prawidłowego ustalenia, w jakich warunkach zachodzi ciągłość czynu, a co za tym idzie, jaki jest zakres prawomocności orzeczenia. W niniejszej pracy Autor posłużył się najdonioślejszymi przykładami orzeczeniami Sądu Najwyższego, które traktują w przedmiocie ciągłości przestępstwa oraz zakresu prawomocności orzeczenia za przestępstwo popełnione $\mathrm{w}$ warunkach ciągłości.

\section{Res iudicata a przestępstwa popełnione w warunkach ciągłości przestępstwa}

Prawomocność orzeczenia znana była już w czasach państwa Hammurabiego. Źródła historyczne pokazują, że sędzia, który sam zmieniał wydany przez siebie wyrok, był pozbawiany możliwości sprawowania urzędu sędziego, a ponadto karany grzywną w wysokości dwunastokrotności roszczenia ${ }^{3}$. Negatywna przesłanka procesowa - res iudicata, tj. powaga rzeczy osądzonej, wraz z ideą, którą z sobą niesie, jest niemal równa wiekiem systemowi prawa kontynentalnego. System ten ewoluował inter

1 Warto wspomnieć, że w czasie, gdy powstawał niniejszy artykuł, została opublikowana - nakładem wydawnictwa C.H. Beck - monografia prawnicza pod redakcją prof. Pawła Wilińskiego oraz prof. Roberta Zawłockiego, która to traktuje kompleksowo w tym przedmiocie, zob. Tożsamość czynu w prawie karnym. Red. P. WiLIŃsKI, R. ZAwŁockI. Warszawa 2021.

${ }^{2}$ M. CIEŚLAK: Polskie prawo karne. Zarys ujęcia systemowego. Warszawa 1994, s. 149.

3 S. Waltoś: Proces karny. Zarys systemu. Warszawa 2002, s. 75. 
alia z prawa rzymskiego ${ }^{4}$, w którym res iudicata pełniła funkcję tożsamą do tej, jaką pełni ona teraz w systemie prawa polskiego. Trzeba także zaznaczyć, że powaga rzeczy osądzonej nie ma charakteru endemicznego dla systemu prawa kontynentalnego, pełni ona bowiem podobną funkcję $\mathrm{w}$ systemie prawa common law ${ }^{5}$. W polskim ustawodawstwie negatywna (mająca charakter formalny ${ }^{6}$ ) przesłanka procesowa rei iudicatae nie jest żadnym novum, występowała w kodeksie postępowania karnego zarówno z 1928 r. ${ }^{7}$ (art. 3), jak i z 1969 r. ${ }^{8}$ (art. 11 pkt. 7), a następnie znalazła swoje miejsce w kodeksie postępowania karnego z 1997 r. ${ }^{9}$, w art. 17 $\S 1$ pkt 7, gdzie ustawodawca jasno stwierdza, że postępowania się nie wszczyna, a wszczęte umarza, jeśli „postępowanie karne co do tego samego czynu tej samej osoby zostało prawomocnie zakończone". Przesłanka ta jest ściśle związana z zagadnieniem prawomocności orzeczenia sądu, w odniesieniu do której wyróżnia się dwa aspekty - formalny oraz materialny. O pierwszym z wymienionych mówimy wówczas, gdy orzeczenie wydane przez sąd nie podlega zaskarżeniu za pomocą zwykłych środków odwoławczych; stan prawomocności formalnej kończy proces karny oraz tworzy stan powagi rzeczy osądzonej. Materialny aspekt prawomocności wynika z jej formalnego aspektu, nie jest bowiem możliwe wszczęcie i prowadzenie postępowania o ten sam czyn przeciwko tej samej osobie, której proces się już formalnie zakończył; aspekt prawomocności materialnej związany jest $\mathrm{z}$ zakazem ne bis in idem ${ }^{10}$ (o czym będzie mowa w dalszej części artykułu). Należy zaznaczyć, że w doktrynie prawa kar-

${ }^{4}$ Zob. M. Rogalski: Przesłanka powagi rzeczy osqdzonej w procesie karnym. Kraków 2005, s. 31-32.

${ }^{5}$ Ibidem, s. 37 i nast. W miejscu tym warto wspomnieć, że res iudicata jest także negatywną przesłanką procesową w postępowaniu karnym przed Międzynarodowym Trybunałem Karnym (arg. ex art. 17 ust. 1 pkt c Rzymskiego Statutu Międzynarodowego Trybunału Karnego sporządzony w Rzymie dnia 17 lipca 1998 r. Dz.U. 2003, nr 78, poz. 708. [Dalej: Statut Rzymski]). Zob. W.A. Schabas, M.M. El Zeidy: Article 17 Issues of admissibility. W: The Rome Statute of the International Criminal Court. A commentary. Eds. O. Triffterer, K. Ambos. München 2016, 781 i nast.; W. GrZeszczyK: Wspótpraca z Międzynarodowym Trybunatem Karnym (rozdziat 66a k.p.k.). „Prokuratura i Prawo” 2005, nr 1, s. 23-32 oraz podane w tych publikacjach orzecznictwo i literatura.

6 J. SKorupKa: Proces karny. Red. J. SKorupKa. Warszawa 2018, s. 236 i nast.

7 Rozporządzenie Prezydenta Rzeczypospolitej z dnia 19 marca 1928 r. Kodeks postępowania karnego. Dz.U. 1928, nr 33, poz. 313.

${ }^{8}$ Ustawa z dnia 19 kwietnia 1969 r. Kodeks postępowania karnego. Dz.U. 1969, nr 13, poz. 96. [Dalej: d.k.k.].

9 Ustawa z dnia 6 czerwca 1997 r. - Kodeks postępowania karnego. Dz.U. 1997, nr 89, poz. 555. [Dalej: k.p.k.].

10 J. SKorupKa: Proces..., s. 240; S. EbensPerger: Strafrechtliches „ne bis in idem“ in Österreich unter besonderer Berücksichtigung internationaler Übereinkommen. „Österreichische Juristen-Zeitung” 1999, Nr. 5, s. 172. 
nego procesowego już samo rozumienie pojęcia prawomocności ani to, jaki wywiera ono wpływ na proces karny, nie są przedmiotem ogólnej zgody $^{11}$. Nie próbując jednak w tym miejscu rozstrzygać tych wątpliwości, należałoby przyjąć, że orzeczenie jest prawomocne w sytuacji, gdy nie jest już możliwe zaskarżenie go $\mathrm{w}$ drodze przewidzianych przez ustawę zwykłych środków zaskarżenia ${ }^{12}$. Res iudicata ma gwarancyjny charakter dla jednostki, który przejawia się tym, że nie może ona zostać ponownie postawiona $\mathrm{w}$ stan oskarżenia $\mathrm{w}$ związku $\mathrm{z}$ tym samym czynem tożsamym podmiotowo-przedmiotowo ${ }^{13}$, co zapobiega bezzasadnemu prowadzeniu ponownego procesu o ten sam czyn ${ }^{14}$. Nie stanowi to jednak, a przynajmniej nie powinno, podstawy do uniknięcia odpowiedzialności przez sprawcę czynu ${ }^{15}$. Problematyka zastosowania instytucji wynikającej z przesłanki rei iudicatae w związku z ciągłością przestępstwa budzi kontrowersje, ponieważ w doktrynie, a przede wszystkim judykaturze, ciężko jest o wypracowanie jednego poglądu na to, co stanowi powagę rzeczy osądzonej, a co nie. Uchwała Sądu Najwyższego z 8 kwietnia 1966 r. $^{16}$ zasadzała się głównie na tym, że konstrukcja przestępstwa ciągłego nie została unormowana $\mathrm{w}$ obowiązującym ówcześnie kodeksie karnym ${ }^{17}$, dlatego też konieczne było, ażeby to doktryna i judykatura podjęły się nadania ,jej takiej postaci, jaka najlepiej odpowiada społecznemu poczuciu sprawiedliwości i umożliwia realizację celów, dla których ta konstrukcja została stworzona" ${ }^{18}$. Ponadto w tej samej uchwale zwrócono uwagę na to, że ujęcie zagadnienia przestępstwa ciągłego nie spełniało swojej roli, bowiem czyny przestępne przybierały coraz to bardziej skomplikowane formy. Wskazany wcześniej judykat został wydany w celu odpowiedzi na pytanie prawne: „Czy skazanie za ściśle określony w czasie fragment przestępstwa ciągłego sprowadza materialną prawomocność osądu co do całości działania przestępnego stanowiącego czyn ciągły, a zatem również co do działania przestępnego wykraczającego poza ramy czasowe, określone zapadłym wyrokiem?" ${ }^{19}$. Sąd Najwyższy zauważył, że jeśli przestępstwo

11 Szerzej w tej kwestii J. Tylman: Polskie postępowanie karne. Red. T. GrzegorczYK, J. Tylman. Warszawa 2011, s. 193 oraz cytowane tam pozycje literatury.

12 Por. P. Hofamíski, E. SADZIK, K. ZgrYZeK: Kodeks postępowania karnego. Komentarz do art. 1-296. T. 1. Red. P. HofmańsKi. Warszawa 2011.

13 J. Skorupka: Proces..., s. 240.

14 S. Waltoś: Proces..., s. 440.

15 A. KaFTAL: O niektórych zagadnieniach tożsamości przedmiotowej czynu przy przestępstwie ciagłym. „Palestra” 1964, nr 8, s. 33.

${ }_{16}$ Uchwała Sądu Najwyższego z dnia 8 kwietnia 1966 r. VI KO 42/62. OSNKW 1966, nr 7, poz. 69.

17 Ustawa z dnia 19 kwietnia 1969 r. Kodeks karny. Dz.U. 1969, nr 13, poz. 96.

18 Ibidem.

${ }^{19}$ Uchwała Sądu Najwyższego z dnia 8 kwietnia 1966 r. VI KO 42/62... 
ciągłe uznać za oparte na konstrukcji jednoczynowej, czyli za jeden czyn przestępny, to nie jest możliwe ponowne sądzenie za nieujawnione na czas orzekania jego elementy, ze względu na jedność czynu. Prowadzi to do konkluzji, że gdyby owe elementy nie mogłyby być określone za samoistne przestępstwa, to winny być uznane za „okoliczności już osądzonego czynu". W doktrynie posłużono się przykładem przemytnika, który to „skazany za wielokrotne bezprawne przekroczenie granicy w określonym okresie, potraktowane jako przestępstwo ciągłe, nie może odpowiadać ponownie przed sądem za dotychczas nie znany wypadek przekroczenia granicy" 20 , i zwrócono uwagę na czas ustalonego przez sąd trwania owego jednego czynu.

W omawianym judykacie Sąd Najwyższy próbował niejako skonstruować przesłanki przestępstwa ciągłego, wskazując, że jeśli uznać je za konstrukcję wieloczynową, to materialna prawomocność nie obejmuje czynów ujawnionych później, które, gdyby zostały wykryte w porę, stanowiłyby części składowe osądzonego już wcześniej przestępstwa ${ }^{21}$. Jednocześnie jednak wyraził pogląd, że ściganie „nowo odkrytego” elementu (czynu) winno być uzależnione od materialnej cechy przestępstwa - społecznego niebezpieczeństwa. Przedstawione ujęcie zostało zaaprobowane przez Zdzisława Papierkowskiego, który zauważył, że z punktu widzenia zarówno doktrynalno-teoretycznego, jak i pragmatyki wymiaru sprawiedliwości owa uchwała była konieczna, a nawet i oczywista. Zgodnie z twierdzeniem Papierkowskiego zastosowanie ówczesnej konstrukcji przestępstwa ciągłego - będącej, na tamten czas, bytem doktrynalno-jurydycznym, a nie mającej żadnej podstawy ustawowej - nie wywoływało materialnej prawomocności orzeczenia zapadłego w związ$\mathrm{ku} \mathrm{z}$ nią, a stosowanie tejże konstrukcji miało na celu realizację zasady ekonomiki procesowej. Wobec czego instytucja przestępstwa ciągłego miała jedynie pomocniczy charakter, natomiast jej stosowanie zależało od dyskrecjonalnej władzy organu stosującego prawo, nie był to - w odróżnieniu od obecnie obowiązującego stanu prawnego - jego obowiązek. Papierkowski uważał, że za przestępstwo ciągłe winna być orzeczona kara łączna. Miało się tak dziać ze względu na to, że stanowi ono jednorodny, realny bieg przestępstw, a także na to, że należy wszczynać postępowanie: „[...] jeżeli kara orzeczona byłaby wyższa, gdyby te nowo ujawnione czyny były znane sądowi w chwili ferowania wyroku. Natomiast nie warto i nie należy wszczynać nowego procesu karnego, jeżeli ujawnione po wydaniu

${ }^{20}$ I. ANDRejew, W. ŚwidA, W. Wolter: Kodeks karny z komentarzem. Warszawa 1973, s. $243-244$.

${ }^{21}$ Cenna jest to uwaga, jeśli uwzględnimy obecną konstrukcję wieloczynowego przestępstwa ciągłego $\mathrm{w}$ postaci szczególnego przypadku realnego zbiegu przestępstw, jakim jest ciąg przestępstw z art. 91 § 1 k.k. 
wyroku czyny i pozostający z nimi w związku wyrok łączny nie orzekałby kary wyższej aniżeli kara wymierzona prawomocnie za przestępstwo ciągłe, tj. czyny ujawnione przed wydaniem prawomocnego wyroku"22. Poglądy te spotkały się jednak z słuszną krytyką przedstawicieli doktryny prawa karnego. Alfred Kaftal zwrócił uwagę na to, że Sąd Najwyższy w sposób całkowicie nieuzasadniony i nieuprawniony dokonał niejako koniunkcji stopnia społecznej szkodliwości czynu z materialną cechą prawomocności. W rezultacie $\mathrm{w}$ jednej sytuacji niektóre elementy przestępstwa ciągłego zostaną uznane za już prawomocnie osądzone i w pełni korzystające z zarzutu rei iudicatae, zaś w innej będzie konieczne ich ponowne osądzenie $\mathrm{z}$ całkowitym pominięciem tejże negatywnej przesłanki procesowej i jej skutków. Co więcej, będzie to jedynie sposób na zaostrzenie represji karnej już poprzednio osądzonego czynu ${ }^{23}$. Wobec tego uprawniona wydaje się konkluzja, że Sąd Najwyższy pozostawał wysoce niekonsekwentny wobec zagadnienia rei iudicatae w stosunku do przestępstw popełnianych w warunkach ciągłości. Andrzej Wąsek słusznie zauważa, że Sąd Najwyższy w omawianej uchwale całkowicie traci z pola widzenia to, że polski proces karny opiera się na zasadzie legalizmu, a nie oportunizmu. $Z$ tego też powodu, jeśli chodzi o czyny popełniane $\mathrm{w}$ sposób ciągły, winny być one traktowane jednakowo, bez względu na ich materialny ciężar ${ }^{24}$. Prawomocność materialna orzeczenia wydanego przez sąd w związku z popełnieniem przez sprawcę czynów (lub czynu) charakteryzujących się ciągłością w latach, kiedy to owe konstrukcje były tylko doktrynalno-jurydyczne oraz kiedy w wyniku wejścia w życie art. 58 d.k.k. stały się konstrukcją normatywną, ale niedookreśloną, budziła w dalszym ciągu raz mniejsze, raz większe kontrowersje. Niemniej jednak z uwagi na temat opracowania oraz na jego ukierunkowanie na obecne unormowania konieczne jest odstąpienie od rekonstrukcji obszernych poglądów judykatury, a przede wszystkim Sądu Najwyższego oraz doktryny dotyczących tegoż zagadnienia ${ }^{25}$. W związku bowiem z podzieleniem jednolitej konstrukcji przestępstwa ciągłego na wieloczynowy ciąg przestępstw oraz

22 Z. PAPIERKOWsKI: Glosa do uchwaty połaczonych Izb Karnej $i$ Wojskowej SN z 8 kwietnia 1966 r., VI KO 42/62. „Państwo i Prawo” 1967, z. 4-5, s. 810-812.

${ }^{23}$ A. Kaftal: Procesowe problemy przestępstwa ciagtego $w$ orzecznictwie Sadu Najwyższego. „Palestra” 1982, z. 1-3, s. 93.

${ }^{24}$ Por. A. WąseK: Problemy z przestępstwem ciagłym. W: Prawo karne i proces karny wobec nowych form i technik przestępczości. Red. H.J. Hirsch, P. HofMańsKi, E.W. PŁYWaczewsKi, C. Roxin. Białystok 1997, s. 79-80.

${ }^{25}$ Zob. w szczególności: Wyrok Sądu Najwyższego z dnia 9 marca 1970 r. IV KR 50/69. LEX nr 1673710; Wyrok Sądu Najwyższego z dnia 10 kwietnia 1974 r. V KR 6/74. OSNKW 1974, nr 7-8, poz. 135, LEX nr 18808; Wyrok Sądu Najwyższego z dnia 12 lutego 1975 r. I KR 226/74. LEX nr 21663; A. Kaftal: Procesowe problemy...; M. CieślaK, J. Waszczyński: Przeglad orzecznictwa Sądu Najwyższego. „Palestra” 1977, z. 7, s. 39; 
jednoczynowy czyn ciągły w wyniku uchwalenia nowego kodeksu karnego w 1997 r. ${ }^{26}$ większość wyrażonych w tym zakresie poglądów się zdezaktualizowała ${ }^{27}$. Nie oznacza to jednak, że straciły one swoją wartość jako źródło w dokonywaniu historycznych porównań unormowań związanych z ciągłością przestępstwa. Można wysunąć nawet tezę śmiałą, acz bynajmniej nie nieuprawnioną, wskazując, że dorobek orzeczniczy judykatury sprzed 1997 r. może być źródłem historycznej interpretacji prawa, tyle że w niektórych sytuacjach a contrario.

Już pod rządami nowych ustaw karnych, zarówno materialnej, jak i procesowej, w 2001 r. Sądowi Najwyższemu zadano pytanie w związku ze sprawą rozpoznawaną przez Sąd Apelacyjny w Poznaniu: „Czy prawomocne osądzenie części zachowań wchodzących w skład czynu ciągłego, o którym mowa w art. 12 k.k., zawsze stanowi ujemną przesłankę procesową w rozumieniu art. $17 \S 1$ pkt 7 k.p.k. odnośnie pozostałych zachowań składających się na ten czyn, które nie były przedmiotem wcześniejszego osądzenia, czy też jest to uzależnione od stosunku stopnia społecznej szkodliwości zachowań już osądzonych do stopnia społecznej szkodliwości zachowań, które osądzone jeszcze nie zostały?"28. Sąd Najwyższy w uchwale z dnia 21 listopada 2001 r. udzielił odpowiedzi na zadane mu pytanie, którą oparł na tezie: „Prawomocne skazanie za czyn ciągły (art. 12 k.k.) stoi na przeszkodzie, ze względu na treść art. 17 § 1 pkt 7 k.p.k., ponownemu postępowaniu o później ujawnione zachowania, będące elementami tego czynu, które nie były przedmiotem wcześniejszego osądzenia, niezależnie od tego, jak ma się społeczna szkodliwość nowo ujawnionych fragmentów czynu cią̧łego do społecznej szkodliwości zachowań uprzednio w ramach tego czynu osądzonych" ${ }^{29}$. Jak to zostało stwierdzone explicite w uzasadnieniu do omawianej uchwały, Sąd Najwyższy odrzucił koncepcję ukształtowaną na gruncie judykatu SN z 1966 r., która zasadzała się na uzależnieniu związania powagą rzeczy osądzonej w zależności od stopnia społecznej szkodliwości zachowań nowo ujawnionych. Sąd Najwyższy zauważył także, że granice czynu z art. 12 k.k. wyznacza początek pierwszego zachowania przestępnego sprawcy oraz koniec ostatniego. Zatem nie powinna nikogo dziwić konstatacja, że wszystkie zachowania

M. Rogalski: Przestanka powagi rzeczy osądzonej w procesie karnym. Kraków 2005, s. 584600 oraz podane tam literatura i orzecznictwo.

${ }^{26}$ Ustawa z dnia 6 czerwca 1997 r. - Kodeks karny. Dz.U. 1997, nr 88, poz. 553. [Dalej: k.k.].

27 L. Gardocki: Prawo karne. Warszawa 1997, s. 145; A. WĄSEK: Kodeks karny. Komentarz. T. 1. Gdańsk 1999, s. 166-176.

${ }^{28}$ Uchwała Sądu Najwyższego z dnia 8 kwietnia 1966 r. VI KO 42/62...

${ }^{29}$ Uchwała Sądu Najwyższego z dnia 21 listopada 2001 r. I KZP 29/01. OSNKW 2002, nr 1-2, poz. 2, LEX nr 49486. 
popełniane przez sprawcę owego czynu będące w związku z nim, wykryte podczas ferowania wyroku czy też nie, powinny być objęte powagą rzeczy osądzonej $^{30}$.

Negatywna przesłanka procesowa rei iudicatae po raz kolejny stała się przedmiotem szeroko zakrojonej dyskusji w doktrynie na kanwie uchwały Sądu Najwyższego z dnia 15 czerwca 2007 r. ${ }^{31}$, którą to podjęto w celu odpowiedzi na pytanie prawne zadane przez Sąd Apelacyjny we Wrocławiu: „Czy prawomocne skazanie za ciąg przestępstw określony w art. 91 § 1 k.k. (a nie za czyn ciągły, o którym mowa w art. 12 k.k.), przy istnieniu przesłanek pozwalających ocenić w toku aktualnie rozpoznawanej sprawy zachowania wchodzące w skład tego ciągu oraz zachowania później ujawnione (które nie były przedmiotem wcześniejszego osądzenia) jako jeden czyn ciągły (art. 12 k.k.) z uwagi na z góry powzięty zamiar wykonania wszystkich tych przestępczych zachowań oraz z uwagi na krótkie odstępy czasu oddzielające owe zachowania, stoi na przeszkodzie umorzeniu postępowania na podstawie art. $17 \S 1$ pkt 7 k.p.k. co do później ujawnionych zachowań, będących obiektywnie - wraz z zachowaniami prawomocnie osądzonymi jako ciąg przestępstw - elementami tego samego czynu ciągłego?”. Sąd Najwyższy w swoim judykacie postawił następującą tezę: „Prawomocne skazanie rodzi powagę rzeczy osądzonej tylko w takim zakresie, w jakim sąd orzekł o odpowiedzialności karnej za zachowania będące przedmiotem zarzutu. Jedynie wówczas, gdy sąd uznał, że objęte jednolitym zamiarem zachowania oskarżonego stanowią jeden czyn zabroniony $\mathrm{w}$ rozumieniu art. 12 k.k., zakres powagi rzeczy osądzonej wyznaczony jest ustalonym w wyroku skazującym lub warunkowo umarzającym czasem jego popełnienia”. Konieczne są w tym miejscu zrekonstruowanie - choć części - poglądów doktryny dotyczących zarówno tezy tegoż orzeczenia, jak i jej uzasadnienia, oraz stypulacja ewentualnych skutków z nich wynikających. Omawiana uchwała zdaje się wysuwać na przód następujące zagadnienia, od których uzależniona jest materialna prawomocność orzeczenia, a co za tym idzie - zakres obowiązywania powagi rzeczy osądzonej: po pierwsze status zachowań składających się na czyn ciągły w odniesieniu do sfery ontologicznej, po wtóre konsekwencje wynikające $\mathrm{z}$ chronologii owych zachowań oraz postępowań, których były one przedmiotem, po trzecie wyrok, jaki został wydany $\mathrm{w}$ danej sprawie, tj. czy był on skazujący, warunkowo umarzający czy też uniewinniający, po czwarte i ostatnie możliwość zmiany kwalifikacji

${ }^{30}$ Por. Uzasadnienie do Uchwały Sądu Najwyższego z dnia 21 listopada 2001 r. I KZP 29/01; podobne zdanie w tym przedmiocie wyraził Sąd Apelacyjny w Katowicach w postanowieniu z dnia 20 czerwca 2001 r. II AKo 92/01. OSPriPr 2002, nr 5, poz. 28, LEX nr 53214.

31 Uchwała Sądu Najwyższego z dnia 15 czerwca 2007 r. I KZP 15/07. OSNKW 2007, nr 7-8, poz. 55, LEX nr 270947. 
prawnej ciągłości przestępstwa z ciągu przestępstw na czyn ciągły, jeśli zachodzą ku temu podstawy.

Odnosząc się do pierwszego z wymienionych zagadnień, Sąd Najwyższy wskazał niejako dychotomiczny podział czynów, na te istniejące obiektywnie, niezależnie więc od jakichkolwiek ocen zachowania sprawcy, oraz te, które są sztucznym konstruktem ${ }^{32}$. Sąd Najwyższy w uzasadnieniu podał, że sąd orzeka w zgodzie z zasadą skargowości procesu karnego w granicach skargi uprawnionego oskarżyciela (art. 14 § 1 k.p.k.) oraz że zakres owej skargi wyznacza wydarzenie historyczne, które to stanowi czyn w znaczeniu naturalnym, co nie oznacza jednak związania sądu kwalifikacją przyjętą przez oskarżyciela ${ }^{33}$. Wskazał także, że konstrukcja wynikająca z art. 12 k.k. jest sztuczna, kreowana przez prawo i nie ma swojego odbicia w rzeczywistości. Owa ,iluzja jedności czynu” wymuszana jest tylko wolą ustawodawcy, który to decyduje się na spięcie zachowań klamrą ciagłości, po spełnieniu pewnych przesłanek, w jeden czyn. Zachowania będące częściami składowymi czynu ciąłego w opinii Sądu Najwyższego należy zatem uznać za czyny sui iuris w znaczeniu ontologicznym, kiedy się je rozpatruje w oderwaniu od instytucji ciaggłości przestępstwa (np. przy okazji innego postępowania karnego). Odnoszac się do przywołanego stanowiska Sądu Najwyższego, należy sformułować wniosek - raczej ogólniejszej natury - że w systemie prawa sensu largo istnieje wiele wyłącznie prawnych konstrukcji, które to nie mają swojego ontologicznego odpowiednika. Nie przeszkadza to jednak nikomu w tym, ażeby uznać je za istniejące faktycznie. Przykładowo wskazać można, że prawo własności jest także tylko konstruktem prawnym, ponieważ jeśliby mówić o własności jedynie w ontologicznym aspekcie, należałoby ją utożsamić z posiadaniem, a - jak wiadomo - tak nie jest. Kategorie czynu wyznaczone przez Sąd Najwyższy nie ułatwiają już i tak skomplikowanej sytuacji wykazania, co właściwie czynem jest, a co nie. Można bowiem odnieść wrażenie, że jeżeli dana konstrukcja ma tylko charakter prawny - istnieje dzięki woli ustawodawcy - z jakiegoś to nieznanego powodu stoi niżej w hierarchii, aniżeli konstrukcje widoczne ,gołym okiem”. Nie

32 Por. Uzasadnienie do uchwały Sądu Najwyższego z dnia 15 czerwca 2007 r. I KZP 15/07; J. GIEZEK: O powadze rzeczy osq̨dzonej w ramach konstrukcji czynu ciagłego. Uwagi na marginesie uchwaty Sadu Najwyższego z 15 czerwca 2007 r. „Czasopismo Prawa Karnego i Nauk Penalnych” 2008, z. 1, s. 83; A. WojTAszczYK, W. ZonTeK: Czy art. 12 k.k. jest ciagtym problemem? „Czasopismo Prawa Karnego i Nauk Penalnych” 2007, z. 2, s. 112 i nast.; P. KARDAS: Res iudicata a konstrukcja czynu ciagtego. „Czasopismo Prawa Karnego i Nauk Penalnych" 2007 , z. 2, s. 63 i nast.

${ }^{33}$ W tym miejscu SN powołuje się na Postanowienie Sądu Najwyższego z dnia 28 listopada 1931 r. II 1K 431/31, 432/31 (Zbiór Orzeczeń Sądu Najwyższego, Orzeczenia Izby Drugiej (Karnej) 1932, z. I, poz. 4), w którym to ówczesny Sąd Najwyższy zajął podobne stanowisko. 
ma wątpliwości co do tego, że przyjęcie ciągłości czynu uznać należy za sztuczne, już chociażby z uwagi na sam fakt czasu oddzielającego elementy czynu ciągłego. To bynajmniej nie oznacza, że można tą konstrukcją dysponować dowolnie. Jak się podkreśla, jej zastosowanie, jeśli zachodzą przesłanki wyznaczone przez ustawodawcę, jest obligatoryjne ${ }^{34}$. Wobec czego nie rolą sądu jest rozstrzyganie, czy ów czyn istnieje w świecie fizycznym czy też nie ani jaki ma on charakter, bo skoro zachodzą przesłanki do zastosowania tej instytucji, sąd jest zobligowany do uczynienia tego. Kwestia ta nie może być przedmiotem deliberacji. Należy pamiętać, że skrajnie naturalistyczne podejście do czynu jako takiego może prowadzić do wniosków absurdalnych z punktu widzenia nie tylko praktyki, ale i teorii prawa. Nawet bowiem w jednolitym na pozór czynie można by wydzielić jeszcze mniejsze jednostki. Sprowadzając rzecz do absurdu, jako przykład można podać strzał dokonany z pistoletu, który to strzał zostanie uznany de lege lata za jeden czyn. Jednakże dokonując jego „rozłożenia na części pierwsze", wskazać można, że każdy przejaw aktywności, np. ruch palcem na spuście czy też wyciagnięcie broni z kabury, może zostać uznany za odrębny czyn. Granice czynu in genere wyznaczane są przez ustawodawcę w sposób sztuczny, czysto spekulatywny ${ }^{35}$. Zasadne jest zatem stanowisko Cieślaka, który pisze, że zachowanie się człowieka z natury nie jest zatomizowane, a wszelkie ramy nakładane nań są wynikiem przyjęcia pewnych konwencji, będących tylko i włącznie wytworem ludzkiego rozumowania ${ }^{36}$. Swoiste wykrawanie pewnych elementów ludzkiej aktywności czy też bierności jest bowiem czynione na użytek różnych kreowanych przez człowieka sytuacji, np. pociągnięcia do odpowiedzialności karnej ${ }^{37}$. Ustawodawca wskazuje każdorazowo przy typizowanym czynie jego znamiona, można, stosując w tym miejscu pewne uproszczenie, stwierdzić, że to właśnie poprzez znamię czasownikowe każdego typu przestępstwa można w dużej symplifikacji określić jeden czyn ${ }^{38}$. Trzeba tu

34 M. DąbRowska-Kardas, P. Kardas: Czyn ciagły i ciag przestępstw w kodeksie karnym z 1997 r. Warszawa 1998, s. 59-60.

35 Por. J. MAJEWsKI: „Ten sam czyn” jako jedna z przestanek kumulatywnej kwalifikacji. W: Zbieg przepisów oraz zbieg przestępstw w polskim prawie karnym. Materiały II Bielańskiego Kolokwium Karnistycznego. Red. J. Majewski. Toruń 2006, s. 43; M. RodzynKIEWICZ: Modelowanie pojęć w prawie karnym. Kraków 1998, s. 28 i nast.

36 Por. M. CIEŚLAK: Polskie...

37 Por. J. GiezeK: O powadze..., s. 87.

38 Bowiem dla wypełnienia znamion czynu w sposób ontologiczny, czy inaczej widoczny, istotne będzie wypełnienie znamienia czasownikowego, tzn. dokonania czasownika. Na wypełnienie czasownika „zabija” i na stwierdzenie jego dokonania w sposób czysto naturalistyczny wpływ będzie miał tylko widoczny gołym okiem efekt działania bądź zaniechania sprawcy. Dopiero na etapie ustalania przypisania odpowiedzialności sprawcy należy dokonać prawnej kwalifikacji czynu sprawcy, będącego wynikiem jego zachowania się, 
wspomnieć, że czyn ciągły (art. 12 k.k.) służy tylko i wyłącznie do określania ciągłości przestępczej działalności sprawcy, która to już z uwagi na jej ustawowy kształt może być zrealizowana „jednoczynowo”; poza obręb zatem możliwości połączenia klamrą ciągłości zostają wysunięte przestępstwa, które to, ze względu na ich typizację, mają pewien aspekt ciągłości, powtarzalności czy też wielokrotności ${ }^{39}$. Wobec tego dziwi stwierdzenie Sądu Najwyższego, że „zachowania” wchodzące w skład czynu ciągłego są czynami w znaczeniu ontologicznym, ogólnie bowiem rzecz ujmując, ciężko jest określić, czym jest czyn naturalny. Racją jest jednak, że niespełnienie przesłanek spowoduje nieuznanie ad casum ciągłości czynu, ponieważ zgodnie z wolą ustawodawcy zastosowanie tejże instytucji wymaga spełnienia jej przesłanek. Niemniej jednak, kiedy już zostaje ona zastosowana, nie można mówić o elementach składowych czynu ciągłego jako o odrębnych czynach w znaczeniu ontologicznym, gdyż przekreślałoby to zasadność istnienia tejże instytucji in genere ${ }^{40}$.

W odniesieniu do drugiej kwestii, tj. chronologii postępowań w związku z nowo ujawnionymi elementami czynu ciągłego po prawomocnym już zań osądzeniu. Nie budzi większych wątpliwości stwierdzenie, że w okresie przyjętym jako ramy czasowe trwania owego czynu, od zachowania początkowego do ostatniego, na kanwie prawomocnego orzeczenia, elementy ujawnione później, nie wymienione w skardze uprawnionego oskarżyciela, nawet o większym stopniu społecznej szkodliwości, objęte są zakresem działania negatywnej przesłanki rei iudicatae $^{41}$. Można pokusić się o stwierdzenie, że elementy graniczne czynu ciągłego konsumują elementy składowe tegoż czynu znajdujące się pomiędzy nimi, i poprzeć je tezą zawartą w omawianej już uchwale Sądu Najwyższego z dnia 21 listopada 2001 r., zgodnie z którą prawomocne

w której zostaje określone, czy zostały wypełnione znamiona ustawowe czynu, czy też $\mathrm{z}$ rozmaitych powodów to nie nastąpiło.

39 Por. M. Dąbrowska-Kardas, P. Kardas: Czyn..., s. 76-77; P. Kardas: Res iudicata..., s. 71 i nast. Wskazywane jest czasami, że owe przestępstwa wieloodmianowe, zbiorowe, trwałe czy też wieloczynowe mają konstrukcję podobną do konstrukcji czynu ciągłego, z uwagi na to, iż naturalistycznie idzie podzielić je na niezależne od siebie części, a dopiero po zastosowaniu pewnej ustawowej konwencji stają się one w „oczach prawa” jednym czynem; zob. Z. ĆWIĄKALsKI: Ujawnienie przestępstwa na podstawie art. $229 \S 6$ k.k. a przyjęcie konstrukcji tzw. czynu ciagtego. W: Nauki penalne wobec problemów współczesnej przestępczości. Księga jubileuszowa z okazji 70. urodzin Profesora Andrzeja Gaberle. Red. K. KrajewsKi. Kraków 2007, s. 30-31.

${ }^{40}$ Por. P. Kardas: Res iudicata..., s. 73 i nast.; J. GIEzeK: O powadze..., s. 88 i nast.; IDEM: Zbieg przepisów a konstrukcja przestępstwa ciagtego. W: Zbieg przepisów oraz zbieg przestępstw $w$ polskim prawie karnym. Materiaty II Bielańskiego Kolokwium Karnistycznego. Red. J. Majewski. Toruń 2006, s. 95 i nast.

${ }^{41}$ Por. w szczególności uzasadnienie do omawianej uchwały Sądu Najwyższego; P. Kardas: Res iudicata..., s. 83 i nast.; J. SKorupKa: Proces..., s. 241-242. 
skazanie za czyn ciągły stoi na przeszkodzie prowadzeniu nowego postępowania o czyny nowo ujawnione a wchodzące w skład osądzonego uprzednio czynu.

Problematyczna staje się sprawa, kiedy przedmiotem wcześniejszego orzekania był element czynu ciąłego, np. stanowiący chronologicznie drugie zachowanie, zaś zachowania pozostałe, pierwsze i ostatnie, maja być przedmiotem postępowania późniejszego. Sąd Najwyższy wskazał, że bezzasadne byłoby przyznanie statusu rei iudicatae wszystkim zachowaniom, które w sytuacji, gdyby były odkryte łącznie, stanowiłyby jeden czyn ciągły. Wskazał również, że winno się prowadzić postępowanie $\mathrm{z}$ pominięciem tegoż elementu w opisie czynu. Co do zasady stanowisko to jest akceptowalne, jednakże należy zaznaczyć, że może się pojawić pytanie, co w sytuacji, jeśli z uwagi na pominięcie tegoż zachowania odstępy czasowe miedzy danymi elementami czynu ciągłego staną się zbyt długie w ustawowym rozumieniu. Jeśli ów czyn ciąły stanowiłby kompilację trzech zachowań, z których środkowe winno być pominięte, te zachowania powinny zostać uznane za realny zbieg przestępstw, czego skutkiem powinno być wymierzenie kary łącznej w wyroku łącznym. W wyniku niedostatecznych działań organów ścigania sprawca zostałby więc surowiej ukarany, aniżeli działoby się to w sytuacji, w której zostałby odkryty cały $\operatorname{czyn}^{42}$. Mając to na uwadze, można wskazać, że dla sprawcy czynu ciągłego w razie zauważenia przezeń, iż uprawniony oskarżyciel zawarł w swojej skardze tylko jeden z elementów owego czynu, bardziej korzystne byłoby wyjawić je wszystkie, ze względu na to, iż w razie późniejszego ich wykrycia może czekać go surowsza kara. Sytuacja taka może być potraktowana jako naruszenie prawa do nieoskarżania samego siebie, które to ustawodawca gwarantuje oskarżonemu w art. 74 $\S 1$ k.p.k. ${ }^{43}$. Można wprawdzie podnieść, że prawo obowiązku na oskarżonego (podejrzanego) nie nakłada, a zatem istnieje wybór między swoistą denuncjacją a jej zaniechaniem. Niemniej jednak zdaje się, że bardziej „opłacalne” byłoby wyjawienie wszystkich elementów czynu przed organami powołanymi do ścigania. Pytanie jednak, czy nie jest to zbyt daleko idące premiowanie osoby $\mathrm{w}$ zasadzie ułatwiającej pracę organom ścigania. Wobec czego - w razie zaniechania samodenuncjacji - może dojść do zwiększenia się negatywnych konsekwencji dla oskarżonego, które wynika nie z jego działania bądź zaniechania, ale z niedostatecznych działań

${ }^{42}$ Por. J. GiezeK: O powadze..., s. 98 i nast.

${ }^{43}$ Zagadnienie to zostało tylko zarysowane $\mathrm{w}$ niniejszym artykule, bowiem w praktyce, ażeby je w całości przeanalizować, konieczne jest poruszenie kwestii kolizji zasad procesu karnego oraz problematyki relacji prawo karne materialne a prawo karne procesowe, co siłą rzeczy wykracza poza ramy niniejszego opracowania. 
organów postępowania przygotowawczego czy też z niezbyt sprawnego ich działania ${ }^{44}$.

Kolejną kwestią jest stwierdzenie Sądu Najwyższego, że stan powagi rzeczy osądzonej konstytuują tylko wyroki sądu będące wyrokami skazującymi oraz warunkowo umarzającymi postępowanie. W uzasadnieniu do omawianej uchwały Sąd Najwyższy wskazał, że jeśli sąd orzekający w sprawie wydał wyrok uniewinniający sprawcę od zarzutu popełnienia czynu ciągłego lub owej instytucji nie zastosował w wyroku skazującym, to zachowania nowo ujawnione moga być przedmiotem chronologicznie późniejszego postępowania wraz z tymi, które były uprzednio rozpatrywane, gdyby to istniały podstawy do przyjęcia konstrukcji czynu ciągłego. Podkreślił także, że res iudicata może obejmować tylko czyny w znaczeniu ontologicznym, nie zaś powstałe na mocy konstrukcji prawnej. Pogląd ten spotkał się z słuszną krytyką ${ }^{45}$ ze strony doktryny. Piotr Kardas zauważa, że ustawodawca nakazuje traktować czyn ciągły jako „ten sam czyn", a co za tym idzie, w związku z zasadą skargowości procesu karnego (art. 14 k.p.k.) oraz w związku z obowiązywaniem zasady prawdy (art. 2 § 2 k.p.k.) i konieczności ustalenia przez sąd całości i rzeczywistego obrazu czynu, konieczne jest zbadanie całego okresu trwania zarzucanego czynu. Prowadzi to do trafnego wniosku, że skoro czyn ciągły stanowi zgodnie z wolą ustawodawcy jedną i nierozerwalną całość z punktu widzenia procesowego, to wynik postępowania jest irrelewantny. Badane są bowiem zachowania, których popełnienie zostało zarzucone w skardze oskarżycielskiej w danym okresie ${ }^{46}$. Jacek Giezek zwraca uwagę na to, że o uniewinnieniu per se nie decyduje samo przyjęcie ciąłłóci, opiera się ono na zupełnie innych podstawach, dlatego ciężko jest zrozumieć różnicowanie wyroków skazujących i uniewinniających pod względem ich prawomocności materialnej ${ }^{47}$. Poglądy Kardasa zostały poddane krytyce przez Michała Rusinka ${ }^{48}$, który zauważa, że „rozciągnięcie konsekwencji prawomocnego osądzenia w przypadku czynu ciągłego nie może wynikać z tego, że zachowania te spełniają materialnoprawne warunki uznania ich za czyn ciągły, ani z tego, że zostały tak ocenione w akcie oskarżenia; efekt

\footnotetext{
44 Podobnie J. GiezeK: O powadze...

45 Ibidem, s. 100 i nast.; P. Kardas: Res iudicata..., s. 88 i nast.

46 P. Kardas: Res iudicata...

47 J. GIEzeK: O powadze...
}

48 M. RusineK: W sprawie uniewinnienia od zarzutu czynu ciagtego $-w$ związku $z$ artykułem P. Kardasa „Res iudicata a konstrukcja czynu ciagłego”. „Czasopismo Prawa Karnego i Nauk Penalnych" 2007, z. 2, s. 101-109; cytowany autor w swojej pracy porusza także kwestię kolizji i „odwiecznego” konfliktu między prawem materialnym a procesowym o pierwszeństwo. Spór ten, niczym spór o inwestyturę, ma swoje dwa skrajnie opozycyjne bieguny oraz stanowiska pośrednie, niemniej jednak omówienie ich w niniejszej pracy znacznie wykracza poza jej ramy. 
ten jest dopiero wynikiem zastosowania przez sąd rozpoznający sprawę konstrukcji z art. 12 k.k. w wyroku - z oczywistych względów może to być tylko wyrok stwierdzający sprawstwo oskarżonego", aprobując tym samym stanowisko Sądu Najwyższego wyrażone w omawianej uchwale, zgodnie z którym czyn ciągły istnieje tylko w przestrzeni prawnej, a jego materialnoprawne pochodzenie nie może być argumentem pozwalającym na stwierdzenie, że może on istnieć niezależnie od unormowań procesowych. Konieczne jest bowiem stwierdzenie istnienia tejże instytucji przez sąd, ażeby mogła ona wywołać skutki prawne w postaci niejako skonsumowania wszystkich zachowań sprawcy popełnionych w związku z zarzucanym czynem. Stanowisko prezentowane przez Sąd Najwyższy, jak również przez Rusinka powinno dziwić z uwagi na to, że zachowania zostały oderwane od okresu, wobec którego ich popełnienie zostało zarzucone. Aprobata takiego stanowiska prowadziłaby do tego, że sąd orzekający w późniejszej sprawie de facto pochylałby się jeszcze raz nad tymi samymi zachowaniami - w odniesieniu do tego samego okresu - które były przedmiotem uprzedniego orzekania. Rusinek w nawiązaniu do argumentu Sądu Najwyższego: „konstrukcja czynu ciągłego służy racjonalizacji karania" wskazuje, że winno się na ten aspekt spojrzeć z punktu widzenia wykładni funkcjonalnej. Objęcie zakresem powagi rzeczy osądzonej w związku z wydaniem wyroku uniewinniającego zachowań w nim nieujawnionych, zdaniem Rusinka, mogłoby prowadzić do paraliżu polityki kryminalnej. Pogląd ów jest chybiony, ponieważ nie można się oprzeć wrażeniu, że różnicowanie prawomocności wyroków uniewinniających ${ }^{49}$ mogłoby stanowić niejako furtkę do „naprawienia” w ocenie innych zapadłych już wyroków. Niezrozumiałe jest bowiem, dlaczego, skoro w postępowaniu kończącym się wydawaniem wyroku zarówno skazującego, jak i uniewinniającego, sąd winien dokładnie zbadać sprawę, a opinia wyrażona przez Rusinka sugeruje, jakoby te drugie wydawane były przez sądy nieco pochopnie. Na marginesie należy zauważyć, że skoro prawomocność rodzą tylko wyroki skazujące, to powoduje to niezwykły paradoks, polegający na tym, że skazanie dla oskarżonego byłoby bardziej korzystne aniżeli uniewinnienie ${ }^{50}$.

Gwoli podsumowania całości, uchwała Sądu Najwyższego z 15 czerwca 2007 r. mimo swej kontrowersyjności stanowi dość ciekawe ujęcie kwestii prawomocności materialnej związanej z zastosowaniem instytucji wynikającej z ciągłości zachowań przestępczych, a powstałe na jej kan-

49 Różne traktowanie wyroków uniewinniających i skazujących było przedmiotem pogłębionej analizy zarówno doktryny, jak i judykatury; zob. w szczególności A. KafTAL: Przestępstwo..., s. 175 i nast.

${ }^{50}$ Por. J. GIEZEK: O powadze... 
wie opracowania są cennym dorobkiem i źródłem cennych informacji dla doktryny prawa karnego zarówno materialnego, jak i procesowego.

W późniejszym orzecznictwie dotyczącym omawianego zagadnienia raz potwierdzano słuszność przywołanych poglądów Sądu Najwyższego ${ }^{51}$, raz wskazywano na słuszność tez o konieczności uznania prawomocności orzeczenia, w którym to sąd zastosował konstrukcję ciągłości do sekwencji zachowań w ograniczeniach czasowych, od początku sekwencyjnie pierwszego elementu do końca ostatniego z nich, tworzących czyn ciągły $^{52}$. Wskazuje się także: ,„[...] istota czynu ciągłego i powaga rzeczy osądzonej sprowadza się do akceptacji, że niedopuszczalne jest prowadzenie postępowania wtedy, gdy miałoby ono dotyczyć zachowania będącego elementem składowym i mieszczącego się w ramach czasowych czynu ciągłego, za który sprawca został prawomocnie skazany. Prawomocne skazanie za czyn ciągły rodzi bowiem powagę rzeczy osądzonej, co wyklucza przypisanie skazanemu kolejnych, takich samych jednostkowych zachowań z okresu opisanego w prawomocnym wyroku" 53 .

Skutkiem prawomocności materialnej jest zakaz sądzenia po raz kolejny za ten sam czyn - zakaz ne bis in idem.

\section{Zasada (zakaz) ne bis in idem}

Niektórzy badacze przedmiotu zwracają uwagę na biblijne pochodzenie tytułowego zakazu i to, że zgodnie ze Starym Testamentem nawet Bóg nie karze dwa razy za to samo, a nieszczęścia (doświadczenia) nie będą zsyłane ponownie na człowieka ${ }^{54}$. Inni zaś twierdzą, że omawiana zasada ogólna procesu karnego ma źródło w prawie rzymskim, w którym utożsamiana była $\mathrm{z}$ inną negatywną przesłanką procesową, a mianowicie rei iudicatae. Ulpian łączył ową zasadę z prawomocnością orzeczeń. Wywodził jej słuszność z zasady: res iudicata pro veritate accipitur, co oznacza, że to, co osądzone, winno zostać uznane za prawdę. Zgodnie z poglądami tego uczonego wyrokom uniewinniającym przypisywano przymiot powagi

${ }^{51}$ Zob. Postanowienie Sądu Najwyższego z dnia 8 kwietnia 2014 r. IV KK 66/14. OSNKW 2014, nr 10, poz. 75, LEX nr 1494018.

52 Zob. Wyrok Sądu Najwyższego z dnia 22 stycznia 2014 r. III KK 439/13. LEX nr 1427468; Wyrok Sądu Najwyższego z 28 sierpnia 2018 r. III KK 389/18. LEX nr 2539905.

${ }^{53}$ Teza do Wyroku Sądu Najwyższego z dnia 22 stycznia 2014 r. III KK 439/13. LEX nr 1427468.

${ }^{54}$ F.C. Schroeder: Die Rechtsnatur des Grundsatzes „ne bis in idem“. „Juristische Schulung" 1997, Nr. 3, s. 228; D.S. RudsteIN: A brief history of the fifth amendment guarantee against double jeopardy. „William and Mary Bill of Rights Journal” 2005, vol. 14, s. 201. 
rzeczy osądzonej ${ }^{55}$. Paulus zaś twierdził, że zastosowanie owej zasady powinno być rozciągnięte na wszystkie wyroki skazujące, gdy tylko stały się one prawomocne ${ }^{56}$. Źródła podają także o istnieniu tejże zasady w prawie starożytnych greckich polis, w którym było zabronione ponowne sądzenie osoby za to samo przewinienie ${ }^{57}$. Demostenes wskazywał na gwarancyjny charakter tegoż zakazu: „prawo zabrania oskarżania dwukrotnie tej samej osoby za ten sam czyn" 58 . Nie rozstrzygając sporów dotyczących pochodzenia i genezy owego zakazu procesowego, warto przytoczyć pogląd Kaftala, który zauważył, że owa zasada jest fundamentalna dla każdego „postępowego ustawodawstwa" 59 . W niemieckiej doktrynie prawa karnego podkreśla się, że zakaz ne bis in idem stanowi jedną z podstawowych zasad procesu karnego, a co za tym idzie, ma decydujący wpływ na jego kształt $^{60}$. Chcąc przedstawić problem związany z uznaniem zakazu ne bis in idem za podstawową zasadę procesu karnego, trzeba wspomnieć o poglądach krytycznych wobec tejże instytucji, dotyczących nie tylko prawa krajowego, ponieważ chodzi tu o zasadę wspólną dla niemalże wszystkich porządków prawa, a ponadto nie jest ona obca postępowaniom toczącym się przed Międzynarodowym Trybunałem Karnym (arg. ex art. 20 w zw. $\mathrm{z}$ art. 17 ust. 1 pkt c Statutu Rzymskiego) ${ }^{61}$.

W systemie common law zakaz ne bis in idem jest ściśle powiązany z instytucją zwaną double jeopardy, która to uniemożliwia bycie oskarżonym w ponownym procesie o ten sam czyn, nawet jeśli wyszły na jaw fakty, które pozwalałyby powątpiewać w niewinność sprawcy, który za niewinnego został uznany we wcześniejszym procesie ${ }^{62}$. Krytycy tejże instytucji zwracają uwagę na to, że nie spełnia ona swojej funkcji, ponieważ jest wykorzystywana przez sprawców przestępstwa w celu uniknięcia odpowiedzialności za dokonane czyny ${ }^{63}$. Wskazuje się też, że w wyni-

55 Por. M. Rogalski: Rzymskie źródła zasady ne bis in idem. „Zeszyty Naukowe Uniwersytetu Rzeszowskiego" 2018, nr 101, s. 115 i nast.

56 J.A. Siglen: A history of double jeopardy. „The American Journal of Legal History” 1963, vol. 7, s. 283; historia i ewolucja zasady ne bis in idem jest zagadnieniem znacząco przekraczającym ramy niniejszej pracy.

57 J.W. Jones: Law and legal theory of the Greeks. Oxford 1956, s. 148.

${ }_{58}$ M.L. Friedland: Double jeopardy. Oxford 1969, s. 15-16. Cytaty z publikacji obcojęzycznych autor podaje w tłumaczeniu własnym.

59 A. Kaftal: Przestęstwo..., s. 173.

${ }^{60}$ Zob. uwaga 271 do art. 103 w: T. Maunz et al.: Grundgesetz-Kommentar. München 1994.

${ }^{61}$ W.A. Schabas, M.M. El Zeidy: Article 17...; I. Tallgren, A. Reisinger Coracini: Article $20 \mathrm{Ne}$ bis in idem. W: The Rome Statute of the International Criminal Court. A commentary..., s. 899 i nast. oraz podane tam orzecznictwo i literatura.

62 Por. P.A. McDermotт: Res judicata and double jeopardy. Butterworths 1999, s. 205.

${ }^{63}$ Zob. W. Comley: Former jeopardy. „Yale Law Journal” 1926, nr 35, s. 681-682. 
ku dużego obciążenia sądów oraz organów ścigania pracą, a nierzadko także niedostatecznego finansowania ich działalności, orzeczenia przez nie wydawane mogą nosić znamiona błędów ${ }^{64}$. Należy jednak pamiętać, że omawiana instytucja, mimo iż obciążona pewnymi wadami, chroni jednostkę przed wszechwładztwem państwa ${ }^{65}$ oraz że aktualnym zdaje się być pogląd wyrażony w XVIII w. przez dublińskiego sędziego Lorda Earlsforta: „,...] podstawowym zadaniem prawa karnego powinni być zapewnienie tego, aby niewinny człowiek nie ucierpiał. Lepiej będzie, jeżeli sprawca nie poniesie zasłużonej kary, niż gdyby miała ucierpieć niewinna osoba"66.

W polskiej doktrynie prawa karnego procesowego zostało zauważone, że zasada ne bis in idem winna zostać określona jako naczelna zasada całego systemu prawa karnego procesowego, wskazano także, że jest ona właściwa nie tylko dla procesu karnego, ale także dla innych, np. cywilnego czy administracyjnego, choć oczywiście w kształcie odpowiadającym tymże procedurom. Maciej Rogalski uznaje zakaz ne bis in idem za podstawową zasadę procesu karnego dlatego, że po pierwsze zakaz ten wynika $\mathrm{z}$ prawa karnego procesowego $-\mathrm{z}$ art. $17 \S 1$ pkt 7 k.p.k, po wtóre jego znaczenie jest podstawowe dla całego procesu, określa on bowiem najistotniejsze cechy procesu oraz jest nadrzędny wobec pozostałych norm procesowych, po trzecie niesie z sobą społeczną i ideologiczną treść, po czwarte posiada dyrektywalny charakter, po piąte bezpośrednio dotyka dziedziny procesu karnego ${ }^{67}$.

Zakaz ne bis in idem wynika z obowiązywania poszanowania prawomocnych orzeczeń, czyli z powagi rzeczy osądzonej ${ }^{68}$. Wskazuje się czasami, że to właśnie zasada ne bis in idem jest pierwotna względem rei iudicatae ${ }^{69}$. Jednakże z tym poglądem trudno się zgodzić, ażeby bowiem powstał stan prawomocności materialnej, z której ów zakaz wynika, konieczne jest powstanie najpierw stanu powagi rzeczy osądzonej, ponieważ to ona jest względem niego pierwotna. Prawomocność materialna oraz wypływająca z niej zasada ne bis in idem powodują, że wszczęcie postępowania przeciwko tej samej osobie o ten sam czyn jest prawnie niedopuszczalne.

${ }^{64}$ J. Resnik: Precluding appeals. „Cornell Law Review” 1942, no. 51, s. 723.

${ }_{65}$ Tak słusznie J.A. SigLER: Double jeopardy: the development of a legal and social policy. Ithaca 1969, s. 194.

${ }_{66}^{6}$ P.A. McDermott: Res judicata..., s. 208.

${ }^{67}$ Por. M. Rogalski: Przestanka powagi..., s. 54-58 oraz podana tam literatura.

${ }^{68}$ Należy zaznaczyć, że dokładne omówienie pierwotności i wtórności w zakresie powagi rzeczy osądzonej i zasady ne bis in idem znacząco wykracza poza ramy niniejszego opracowania. W pamięci trzeba mieć to, że istnieją poglądy zupełnie odmienne od prezentowanego w tymże opracowaniu.

${ }^{69}$ F. Prusak, A. Kordik, Z. Świda: Prawo karne procesowe. Część ogólna. Red. F. PrusaK. Wrocław 1995/1996, s. 52. 
Wykrycie istnienia tejże negatywnej przesłanki skutkuje umorzeniem postępowania. Złamanie zakazu ne bis in idem stanowi bezwzględną przyczynę uchylenia orzeczenia (art. $439 \S 1$ pkt 8 k.p.k.). Ów zakaz procesowy dotyczy nie tylko postępowania sądowego, ale także postępowania przygotowawczego, które było prowadzone $\mathrm{w}$ fazie in personam. Jest to warunek konieczny obowiązywania tegoż zakazu; postępowanie przygotowawcze, które nie wyszło poza fazę in personam, a zostało umorzone na mocy postanowienia prokuratora, nie cieszy się statusem powagi rzeczy osądzonej w przeciwieństwie do postanowienia umarzającego postępowanie na podstawie art. $17 \S 1$ pkt 3 k.p.k ${ }^{70}$.

Zarówno doktryna, jak i orzecznictwo nie są zgodne, jeśli chodzi o zakres zastosowania zakazu ne bis in idem $\mathrm{w}$ przypadku popełnienia przestępstw, które mają charakter ciągły. Pojawiają się spory w podobnych kwestiach, jakie są podnoszone $\mathrm{w}$ związku z powagą rzeczy osądzonej, tj. dotyczące problematyki tożsamości czynu, co do którego toczyło się postępowanie wcześniejsze, oraz tego, co do którego proces ma dopiero co się toczyć, kwestią sporną jest także charakter orzeczenia kończącego postępowanie. Zostało zauważone w wyroku Sądu Najwyższego z 24 października $1935 \mathrm{r}^{71}$, że osądzenie czynu popełnionego w ciągłości pokrywa wszystkie jego elementy, czy były one znane sądowi czy też nie. Jednakże w tym samym orzeczeniu Sąd Najwyższy stwierdził, że konieczne jest rozróżnienie skutków wyroków uniewinniających od skutków wyroków skazujących oraz że: „[...] przy skazującym wyroku zasada rzeczy osądzonej dotyczy wszystkich, nawet nie ujawnionych fragmentów działania. Przy uniewinniającym wyroku działanie rozdziela się na szereg pojedynczych czynów, co do których stosuje się zasada ne bis in idem tylko o tyle, o ile zostały osądzone jako samodzielne przestępstwa. Nic nie stoi na przeszkodzie, żeby inne, przy pierwszym sądzeniu nieznane czyny stały się przedmiotem nowego postępowania, przy którym sąd może ustalić, ale tylko między nimi, ciągłość działania”. Pogląd ten spotkał się jednak z krytyką doktryny ${ }^{72}$. Kaftal zauważa, że skoro zarówno wyrok skazujący, jak i uniewinniający zasadzają się na tym, iż przedmiotem deliberacji sądu było zdarzenie faktyczne stanowiące przestępstwo ciągłe, to bez znaczenia jest wynik sprawy. W obu bowiem przypadkach sąd może objąć tylko te elementy, które były fragmentami czynu ciągłego, a pozostawia pozostałe

70 Por. J. SKorupKa: Proces..., s. 240-242.

${ }^{71}$ Wyrok Sądu Najwyższego z dnia 24 października 1935 r. I K 675/33. Orzecznictwo Izby Karnej SN 1936, z. VI, poz. 216.

${ }^{72} \mathrm{~W}$ niemieckiej doktrynie prawa karnego został wygłoszony podobny pogląd, jednakże i tam spotkał się on z krytyką; zob. w szczególności G. GRüNwALD: Die materielle Rechtskraft im Strafverfahren der Bundesrepublik Deutschland. „Zeitschrift für die gesamte Strafrechtswissenschaft" 1974, Nr. 86, s. 115. 
poza zasięgiem swojego orzekania' ${ }^{73}$. W uchwale z 8 kwietnia 1966 r. Sąd Najwyższy wskazał, że w stosunku do czynu ciągłego nie zachodzi prawomocność materialna nowo ujawnionych czynów wchodzących w skład tejże prawnej konstrukcji ${ }^{74}$. Jednakże $\mathrm{w}$ wyniku uznania przez ustawodawcę w 1997 r. jednoczynowej konstrukcji czynu ciągłego ów pogląd stał się nieaktualny. Wyrazem czego jest stanowisko najwyższej instancji przedstawione w uchwale z dnia 21 listopada $2001 \mathrm{r}^{75}$ : „Przyjęcie tej konstrukcji »czynu ciągłego « przesądza o konieczności stosowania zasady ne bis in idem procedatur wyrażonej w art. 17 § 1 pkt 7 k.p.k., stwierdzającej, iż nie wszczyna się postępowania, a wszczęte umarza, gdy postępowanie karne co do tego samego czynu tej samej osoby zostało prawomocnie zakończone. Ocena stopnia szkodliwości społecznej wcześniej ujawnionych i osądzonych prawomocnie zachowań składających się na czyn ciągły oraz zachowań ujawnionych później nie ma zatem znaczenia dla kwestii prawomocności czynu ciągłego". Konieczne jest w tym miejscu zilustrowanie sytuacji, w której to sprawca popełnia trzy przestępstwa będące w ciągu, w rozumieniu art. 91 § 1 k.k. - oznaczmy je: a1, a2, a3, z czego przestępstwa a1 i a3 zostają wykryte i prawomocnie osądzone. W stosunku do tychże wytworzył się stan rzeczy osądzonej i obowiązuje zakaz ne bis in idem. Nie dotyczy to zaś przestępstwa a2, z uwagi na to, że konstrukcja ciągu przestępstw opiera się na realnym zbiegu przestępstw, każde z nich było czynem sui iuris, nie tak jak w przypadku czynu ciągłego z art. 12 $\S 1$ k.k., kiedy przestępstwo stanowi element jednego i tego samego czy$\mathrm{nu}^{76}$. W odniesieniu do instytucji ciągu przestępstw w pełni aktualne jest zatem stanowisko Sądu Najwyższego wyrażone w uchwale z dnia 8 kwietnia 1966 r.: „materialna prawomocność osądu czynów ujętych jako przestępstwo ciągłe nie obejmuje nowo ujawnionych czynów, które w razie ich wcześniejszego ujawnienia weszłyby w skład przestępstwa ciągłego" "77.

Zasada ne bis in idem $\mathrm{w}$ polskim porządku prawnym nie wypływa expressis verbis z Konstytucji $\mathrm{RP}^{78}$, jak np. w Niemczech, gdzie istnienie tejże instytucji prawnej wywodzone jest z art. 103 Konstytucji RFN, który stanowi: „Nikt nie może być wielokrotnie karany za ten sam czyn na podsta-

73 A. KaFtaL: O niektórych zagadnieniach zmiany kwalifikacji czynu na tle orzecznictwa. „Państwo i Prawo” 1962, z. 8-9, s. 36-38.

${ }^{74}$ Por. Uzasadnienie do uchwały Sądu Najwyższego z dnia 8 kwietnia 1966 r. VI KO 42/62. OSNKW 1966, nr 7, poz. 69.

${ }^{75}$ Uzasadnienie uchwały Sądu Najwyższego z dnia 21 listopada 2001 r....

${ }^{76}$ M. DąbRowska-Kardas, P. Kardas: Czyn ciagły..., s. 121-122; M. Rogalski: Res iudicata..., s. 603.

77 Por. Uzasadnienie do uchwały Sądu Najwyższego z dnia 8 kwietnia 1966 r. VI KO 42/62. OSNKW 1966, nr 7, poz. 69.

${ }^{78}$ Zob. M. Rogalski: Res iudicata..., s. 58 i nast. 
wie powszechnie obowiązujących ustaw karnych"79. W modelu niemieckim uznaje się za niedopuszczalne ponowne sądzenie już po skazaniu, a nie dopiero po odbyciu kary, wykluczone jest także ponowne sądzenie za ten sam czyn, jeśli został on wcześniej objęty wyrokiem uniewinniającym $^{80}$. Niemniej jednak nie jest tak, że obowiązywanie zasady ne bis in idem $\mathrm{w}$ polskim porządku prawnym nie posiada swoich konstytucyjnych źródeł. Trybunał Konstytucyjny wyinterpretował omawiany zakaz $\mathrm{z}$ art. 2 Konstytucji RP, podkreślając, że jest to jedna $\mathrm{z}$ fundamentalnych zasad prawa właściwa i stanowiąca jeden z elementów demokratycznego państwa prawnego, które to jest realizacją zasady sprawiedliwości społecznej. Podwójne nałożenia środka represyjnego za ten sam czyn jest złamaniem tejże zasady ${ }^{81}$. Konstytucyjnym źródłem zasady ne bis in idem jest także art. 9 Konstytucji RP, stanowiący o obowiązku przestrzegania przez państwo prawa międzynarodowego, zaś z systemu prawa międzynarodowego wywodzi się obowiązek przestrzegania omawianego zakazu. Jego podstaw doszukiwać się należy w art. 11 ust. 1 Powszechnej Deklaracji Praw Człowieka ${ }^{82}$, art. 6 ust 2 Europejskiej Konwencji Praw Człowieka ${ }^{83}$ oraz art. 14 ust. 2 Międzynarodowego Paktu Praw Obywatelskich i Politycznych ${ }^{84}$. Obowiązywanie omawianej zasady jest także realizacją zobowiązania międzynarodowego wynikającego z faktu członkostwa Polski w Unii Europejskiej, bowiem zgodnie z art. 50 Karty praw podstawowych UE: „Nikt nie może być ponownie sądzony lub ukarany w postępowaniu karnym za ten sam czyn zabroniony pod groźbą kary, w odniesieniu do którego zgodnie z ustawą został już uprzednio uniewinniony

79 Art. 103 (3) „Niemand darf wegen derselben Tat auf Grund der allgemeinen Strafgesetze mehrmals bestraft warden"; por. uwaga 1 do art. 103 w: B. SCHMIDT-BLEIBTREU, F. KLEIN: Kommentar zum Grundsetz für die Bundesrepublik Deutschland, unter Mitarbeit von Hans Bernhard Brockmeyer. Frankfurt am Main 1990.

${ }^{80}$ G. GRüNWALD: Die materielle..., s. 96.

${ }^{81}$ Por. Stanowisko Rzecznika Praw Obywatelskich z dnia 18 listopada 2015 r. II.510.1123.2015.MK; Wyrok Trybunału Konstytucyjnego z dnia 21 października 2015 r. P 32/12. Dz.U. 2015, poz. 1742; Wyrok Trybunału Konstytucyjnego z dnia 18 listopada 2010 r. P 29/09. OTK-A 2010, nr 9, poz. 104; Wyrok Trybunału Konstytucyjnego z dnia 29 kwietnia 1998 r. K 17/97. OTK 1998, nr 3, poz. 30; Wyrok Trybunału Konstytucyjnego z dnia 4 września 2007 r. P 43/06. OTK-A 2007, nr 8, poz. 95.

${ }^{82}$ Powszechna Deklaracja Praw Człowieka. Rezolucja Zgromadzenia Ogólnego ONZ 217 A (III) z dnia 10 grudnia 1948 r. https://www.ohchr.org/EN/UDHR/Pages/Language. aspx?LangID=pql [dostęp: 9.11.2021].

${ }^{83}$ Konwencja o Ochronie Praw Człowieka i Podstawowych Wolności sporządzona w Rzymie dnia 4 listopada 1950 r., zmieniona następnie Protokołami nr 3, 5 i 8 oraz uzupełniona Protokołem nr 2. Dz.U. 1993, nr 61, poz. 284. [Dalej: Konwencja, EKPCz].

${ }^{84}$ Por. P. KrawczyK: Rozważania na temat ciagtości przestępstwa $w$ nawiązaniu do zmian dokonanych $w$ polskim prawie karnym nowelizacja kodeksu karnego $z$ dnia 4 października 2018 roku. „Studenckie Zeszyty Naukowe WPiA UMK” 2019, nr 2 (2), s. 23-28. 
lub za który został już uprzednio skazany prawomocnym wyrokiem na terytorium Unii" ${ }^{85}$. Trybunał Sprawiedliwości Unii Europejskiej (TSUE) nie przyznaje zasadzie ne bis in idem charakteru absolutnego, niemniej jednak w orzecznictwie Trybunału wskazuje się, że możliwość multiplikacji sankcji represyjnych powinna mieć charakter wyjątkowy, a co jeszcze istotne, wszelkie odstępstwa od stosowania zasady ne bis in idem powinny być określone według maksymalnie precyzyjnych kryteriów ${ }^{86}$. Z orzecznictwa TSUE da się wyprowadzić przesłanki, które pozwolą wyłączyć stosowanie zakazu ne bis in idem w konkretnym postępowaniu i które umożliwią ukaranie sprawcy za ten sam czyn w ramach dwóch postępowań. Po pierwsze muszą one być motywowane realizacją ogólnego interesu, który będzie uzasadniał kumulację sankcji i postępowań, a do tego winny służyć realizacji celów dodatkowych; po wtóre postępowania muszą być oparte na zasadach ograniczających, do ściśle niezbędnego, dodatkowy ciężar ponoszony przez osoby dotknięte ową kumulacją postępowań; po trzecie surowość wszystkich nałożonych sankcji winna być adekwatna do ciężaru gatunkowego przestępstwa ${ }^{87}$. Trybunał dopuszcza jednak tzw. konstrukcję idealnego zbiegu przestępstwa, w której to jedno działanie (bądź zaniechanie) sprawcy narusza dwie normy prawa kryminalnego, jednakże w takiej sytuacji kara wyższa pochłania na zasadzie konsumpcji karę niższą. W związku z czym sytuacja nie narusza zakazu $\mathrm{z}$ art. 4 Protokołu nr $7 \mathrm{EKPCz}$, gdyż zabrania on powtórnego sądzenia za to samo przestępstwo, zaś w konstrukcji tzw. zbiegu idealnego mamy do czynienia z dwoma różnymi przestępstwami i nie ma znaczenia, że ich znamiona wyczerpuje jedno działanie (zaniechanie) ${ }^{88}$. Pogląd ten krytykowany jest w doktrynie, z uwagi na to, że już w sprawie Zolotuchin Europejski Trybunał Praw Człowieka (ETPCz) wskazał, iż irrelewantna jest kwalifikacja prawna czynu, zaś co ma znaczenie, to właśnie tożsamość zachowania, które wyczerpuje znamiona typu czynu ${ }^{89}$.

${ }^{85}$ Karta praw podstawowych Unii Europejskiej. Dz.U. UE 26.10.2012, C 326/392.

${ }_{86}$ Zob. P.H. van Kempen, J. Bemelmans: EU protection of substantive criminal law principles of guilt and ne bis in idem under the Charter of Fundamental Rights: Underdevelopment and overdevelopment in an incomplete criminal justice framework. „New Journal of European Criminal Law" 2018, no. 2, s. 247.

${ }^{87}$ Por. J. GiezeK, P. KaRdas: Zasada ne bis in idem a nowe regulacje ciagłości przestępstwa. „Palestra” 2019, nr 4, s. 7-8; Wyrok Trybunału Sprawiedliwości Unii Europejskiej (Wielka Izba) z 20 marca 2018 r. w sprawach połączonych C - 596/16 i C - 597/16 Enzo Di Puma oraz Menci.

88 Zob. Wyrok Europejskiego Trybunału Praw Człowieka z dnia 30 lipca 1998 r. w sprawie Oliveira v. Szwajcaria. Skarga nr 25711/94.

89 Por. M. Jackowski: Zasada ..., s. 29, oraz zdanie odrębne sędziego B. Replika w sprawie Oliveira v. Szwajcaria. Skarga nr 25711/94. 
Na orzecznictwo Trybunału Sprawiedliwości Unii Europejskiej bez wątpienia ma wpływ orzecznictwo organu sądowniczego Rady Europy Europejskiego Trybunału Praw Człowieka. Konwencja o Ochronie Praw Człowieka i Podstawowych Wolności stanowi podstawę orzekania ETPCz. Wprawdzie w jej zapisach nie został ów zakaz wyrażony expressis verbis ${ }^{90}$, niemniej jednak w Protokole 7 do owego aktu normatywnego, stanowiącym dopełnienie zapisów Konwencji, a zarazem jej integralną część, w artykule 4 ust. 1 znalazło się postanowienie: „Nikt nie może być ponownie sądzony lub ukarany w postępowaniu przed sądem tego samego państwa za przestępstwo, za które został uprzednio skazany prawomocnym wyrokiem lub uniewinniony zgodnie $\mathrm{z}$ ustawą i zasadami postępowania karnego tego państwa". W sprawie Storbråten v. Norwegia wskazane zostało przez trybunał strasburski, że w celu ustalenia, czy doszło do „skazania za przestępstwo", konieczne jest ustalenie wpływu czynników takich, jak: kwalifikacja prawna czynu, natura czynu, stosowany środek oraz jego cel i stopień dolegliwości, a także ustalenie, czy ów środek reakcji represyjnej został zastosowany przed czy po skazaniu oraz w toku jakiego postępowania został zastosowany ${ }^{91}$. W stosunku do zwrotu użytego w Konwencji, tj. „to samo przestępstwo”, ETPCz w sprawie Gradinger v. Austria wskazał, że dla spełnienia przesłanki tożsamości przestępstwa konieczne jest wykazanie, iż zasadnicze znaczenie ma postępowanie tej samej osoby, zaś irrelewantna jest kwalifikacja prawna czynu ${ }^{92}$. Trybunał wytworzył koncepcję tzw. istotnych elementów, sprowadzającą się do tego, że prowadzenie kolejnego postępowania karnego przeciwko temu samemu sprawcy, przeciwko któremu już został zakończony proces o czyn, i w sytuacji, kiedy istotne elementy czynów zarzucanych w obu procesach można uznać za wspólne, będzie stanowiło naruszenie art. 4 Protokołu nr 7 Konwencji. Przestępstwo, które by podlegało sądzeniu jako wtórne, byłoby bowiem, zdaniem ETPCz, jedynie „nominalnie odmienne" ${ }^{93}$. W sprawie Franz Fischer v. Austria podkreślono, że zakaz powtórnego karania odnosi się do procesu karnego, który zakończył się wydaniem prawomocnej decyzji. Konieczne jest także odniesienie się do kryteriów ustalonych w sprawie

${ }^{90}$ Postanowienie Europejskiego Trybunału Praw Człowieka z dnia 14 września 1999 r. w sprawie Ponsetti i Chesnel v. Francja, skargi nr 36855/97 i 41731/98.

${ }_{91}$ Wyrok Europejskiego Trybunału Praw Człowieka z dnia 1 lutego 2007 r. w sprawie Storbråten v. Norwegia. Skarga nr 12277/94.

92 Wyrok Europejskiego Trybunału Praw Człowieka z dnia 23 października 1995 r. w sprawie Gradinger v. Austria. Skarga nr 15963/90.

93 Por. M. Jacкоwsкi: Zasada ne bis in idem $w$ orzecznictwie Europejskiego Trybunatu Praw Człowieka. „Państwo i Prawo” 2012, nr 9, s. 21; zob. także Wyrok Europejskiego Trybunału Praw Człowieka z dnia 30 maja 2002 r. w sprawie W.F. v. Austria. Skarga nr 38275/97; Wyrok Europejskiego Trybunału Praw Człowieka z dnia 6 czerwca 2002 r. w sprawie Sailer v. Austria. Skarga nr 38237/97. 
Engel i in. v. Holandia, które w odniesieniu do art. 6 EKPCz należy interpretować, biorąc pod uwagę po pierwsze prawną kwalifikację naruszenia zgodnie z normami prawa krajowego, po drugie charakter czynu, po trzecie stopień dolegliwości kary grożącej sprawcy ${ }^{94}$. W sprawie Zolotuchin v. Rosja ${ }^{95}$ ETPCz zaznaczył, że ukaranie za wykroczenia przeciwko porządkowi publicznemu stanowi skazanie za przestępstwo ${ }^{96} \mathrm{w}$ świetle art. 4 Protokołu 7 EKPCz. Stwierdzono, że niesłuszne byłoby przyjęcie wąskiego rozumienia znaczenia słowa „przestępstwo”, a w szczególności kwalifikacja prawna czynu nie powinna być wyznacznikiem tożsamości przestępstwa, taka bowiem wykładnia byłaby zbyt wąska i podważałaby sens gwarancyjnego charakteru normy konwencji. Mając to na uwadze, ETPCz wskazał, że art. 4 Protokołu 7 EKPCz winien być postrzegany jako zakaz ponownego oskarżenia lub sądzenia, jeżeli drugie przestępstwo (w rozumieniu Konwencji) wynika z faktu bądź faktów, które w zasadzie są takie same. Jeśli jednak chodzi o ponowne oskarżenie lub sądzenie $\mathrm{w}$ tej samej sprawie, to Trybunał wskazał, że jest konieczne, aby konkretne okoliczności faktyczne związane z działalnością przestępczą jednego oskarżonego były nierozerwalnie połączone w czasie i przestrzeni, tak aby stanowiły podstawę skazania lub wszczęcia procesu karnego w uprzednim postępowaniu ${ }^{97}$.

Zasada ne bis in idem ma charakter gwarancyjny, jest dopełnieniem aspektu prawomocności materialnej orzeczenia - powagi rzeczy osądzonej (rei iudicatae). Zabezpiecza jednostkę przed wtórnym sądzeniem, a w efekcie skazaniem za ten sam czyn. Jak wskazuje zasadnie TSUE, zasada ne bis in idem jest przejawem ochrony przed państwowym ius punien$d i^{98}$. Stanowi emanację szeroko rozumianej sprawiedliwości i racjonalizacji karania. Jak to zostało przedstawione, koncept zakazu powtórnego karania nie jest novum, obecny był on w prawie niemalże od samego początku istnienia naszej cywilizacji. Oczywiście zmieniał się w czasie i był

94 Por. M. JAcкоwsкi: Zasada..., s. 20-23 oraz podane tam orzecznictwo; P. HofmańsKI, A. Wróbel: Komentarz do art. 6. W: Konwencja o Ochronie Praw Człowieka i Podstawowych Wolności. Komentarz. T. 1. Red. L. GarLICKI. Warszawa 2010, s. 286-287.

${ }_{95}$ Wyrok Wielkiej Izby Europejskiego Trybunału Praw Człowieka z dnia 10 lutego 2009 r. w sprawie Zolotuchin v. Rosja. Skarga nr 14939/03.

96 W polskiej doktrynie prawa karnego sensu largo charakter odpowiedzialności sprawcy wykroczenia również nie jest przedmiotem powszechnej zgody; zob. P. KrawczYK: Rozważania... oraz podane tam orzecznictwo i literatura.

97 Por. M. JАскоwsкi: Zasada..., s. 24.

98 Opinia Rzecznika Generalnego D. Ruiza-Jaraba Colomera przedstawiona w dniu 8 czerwca 2006 r. w sprawie Van Straaten, C-150/05; Opinia Rzecznika Generalnego E. Sharpston przedstawiona w dniu 15 czerwca 2006 r. w sprawie Gasparini, C-467/04; Opinia Rzecznika Generalnego D. Ruliza-Jaraba Colomera przedstawiona w dniu 20 października 2005 r. w sprawie Van Esbroeck, C-436/04. 
różnie rozumiany $\mathrm{w}$ różnych społeczeństwach, niemniej jednak zarówno teraz, jak i w przyszłości powinien on ewoluować w stronę bardziej restrykcyjnego jego przestrzegania, aniżeli stosowania go okazyjnie. Nie powinno nikogo dziwić stwierdzenie, że zakaz ne bis in idem, obecny na gruncie prawa zarówno krajowego, jak i międzynarodowego, należy uznawać za jedną z podstaw właściwej realizacji praw człowieka względem jednostki, jest on bowiem skierowany nie bezpośrednio do jednostki, ale do organów państwowych.

\section{Podsumowanie}

Dość szeroko omawiana uchwała Sądu Najwyższego z dnia 15 czerwca 2007 r. może posłużyć za przykład nadmiernego skomplikowania zagadnienia tożsamości czynu, a także problematyczności wyznaczania granic prawomocności orzeczenia $\mathrm{w}$ procesie karnym.

Jak było zaznaczone w niniejszym artykule, właściwe zdaje się stanowisko, że „najwyższa instancja” w wyniku niemożności dostosowania konstrukcji czysto teoretycznych do rzeczywistości całkowicie zatraciła cel, $\mathrm{w}$ jakim powinno się posługiwać pojęciem czynu. Mając wszak w pamięci pogląd wyrażony przez Cieślaka, przywołany na początku niniejszego opracowania, nie sposób nie wysnuć wniosku, że nieco sztuczna wydaje się dywersyfikacja postrzegania czynów na te możliwe do ontologicznego ujęcia oraz te, które oparte są na konstrukcjach ustawowych. Nasuwa się w związku z tym określenie „nie-czyn”, może dość niezgrabne, niemniej oddające w pewnym sensie ów pogląd, który to można sprowadzić do postrzegania czynu ciagłego jako „nie-czynu” na gruncie prawa karnego materialnego. Poprzednie zdanie powinno wzbudzić pewien opór w czytelniku z uwagi na to, iż nie można tracić z pola widzenia, że niezależnie od tego, czy czyn stanowił jednoczynową realizację znamion przestępstwa czy też był przestępstwem „popełnionym na raty”, ich status jest taki sam. Beznadziejne wydaje się kruszyć kopię - z punktu widzenia odpowiedzialności karnej - w sporach o jedyny i właściwy sposób konstrukcji i wyznaczania granic czynu. Wszak snucie teorii $\mathrm{w}$ tym przedmiocie, często nader skomplikowanych, powoduje ogólne - nie przebierając w słowach - zamieszanie i zakłopotanie. Prowadzić to może do niezrozumienia i zatracenia samej istoty rzeczy, która w konsekwencji dotyka jednostkę. Za tym często podąża skutek społeczny, jakim jest powszechne w społeczeństwie niezrozumienie prawniczych konstrukcji. Problem jest o tyle istotny, że na gruncie orzeczeń zapadających w postępowaniu karnym często rozwijają się szeroko zakrojone dyskusje publiczne. Nadmierne skomplikowanie istoty rzeczy przyczynia się do powstania poczucia niesprawiedliwości 
(czy to in minus - niesłusznego ukarania, czy to in plus - ukarania ponad miarę). Prowadzić to może do tego, że w opinii społeczeństwa - w przenośni oczywiście - winno się słowo Szekspirowskiego rzeźnika zamienić w czyn. W związku z tym aktualna jak nigdy zdaje się łacińska paremia summum ius summa iniuria.

Wobec rozważań przedstawionych $\mathrm{w}$ artykule $-\mathrm{w}$ opinii autora $-\mathrm{za}$ uzasadniony można uznać wniosek, że należałoby postrzegać konstrukcje związane z ciągłością przestępstwa nie tylko przez pryzmat zapisów ustawowych i skupić się w większym stopniu na poszukiwaniu uzasadnienia wprowadzenia ich w otaczającej nas rzeczywistości. Wszak - zdaje się ustawodawca w 1997 r. dostrzegał złożoność problemu wyznaczania granic czynu i starał się rozwiązać ową kłopotliwą sytuację, wprowadzając do polskiego sytemu prawa karnego konstrukcje związane z szeroko rozumianą ciągłością przestępstwa $\mathrm{w}$ jej ustawowo sklasyfikowanym modelu. Konieczność redukcji wielości ocen nie wynika przecież z chęci ułatwienia pracy organom wymiaru sprawiedliwości, a już na pewno nie z chęci „premiowania” sprawców przestępstw ciągłych sensu largo, tylko umotywowane jest koniecznością utworzenia podstaw ustawowych do możliwie jak najdokładniejszego opisania czynu za pomocą ustawowych instytucji. Wobec tego wydaje się - mimo swoistej osobliwości takiego poglądu - że jest konieczne pozbawione wszystkich zbędnych ozdobników, wręcz brutalistyczne, podejście do postrzegania zachowań ujętych klamrą ciągłości jako jednego czynu.

Niemniej jednak wskazać należy, że problematyka zakresu stosowania rei iudiactae oraz zakazu ne bis in idem w odniesieniu do czynów powstałych na podstawie połączenia ich klamrą ciągłości - w zgodzie z ustawowymi przesłankami - budzi wielkie kontrowersje. Mimo upływu czasu problem ten pozostaje nierozwiązany. Dlatego też, wyzbywając się płonnych nadziei, można skonstatować, że wątpliwe jest, ażeby w niedalekiej przyszłości zostało wypracowane stanowisko, które zadowoliłoby - choć w niewielkim stopniu - wszystkich.

\section{Bibliografia}

\section{Literatura}

ANDReJeW I., ŚwiDA W., Wolter W.: Kodeks karny z komentarzem. Warszawa 1973. CIEŚLAK M.: Polskie prawo karne. Zarys ujęcia systemowego. Warszawa 1994.

Cieślak M., Waszczyński J.: Przegląd orzecznictwa Sądu Najwyższego. „Palestra” 1977, z. 7.

CoMley W.: Former jeopardy. „Yale Law Journal” 1926, nr 35.

ĆWIĄALSKI Z.: Ujawnienie przestępstwa na podstawie art. $229 \S 6$ k.k. a przyjęcie konstrukcji tzw. czynu ciagłego. W: Nauki penalne wobec problemów współczes- 
nej przestępczości. Księga jubileuszowa z okazji 70. urodzin Profesora Andrzeja Gaberle. Red. K. KrajEWSKI. Kraków 2007.

DąBROWSKA-Kardas M., Kardas P.: Czyn ciagty $i$ ciag przestępstw w kodeksie karnym z 1997 r. Warszawa 1998.

EBENSPERGER S.: Strafrechtliches „ne bis in idem“ in Österreich unter besonderer Berücksichtigung internationaler Übereinkommen. „Österreichische JuristenZeitung" 1999, Nr. 5.

Friedland M.L.: Double jeopardy. Oxford 1969.

GARDOCKI L.: Prawo karne. Warszawa 1997.

GIEZEK J.: O powadze rzeczy osqdzonej w ramach konstrukcji czynu ciagłego. Uwagi na marginesie uchwały Sadu Najwyższego z 15 czerwca 2007 r. „Czasopismo Prawa Karnego i Nauk Penalnych" 2008, z. 1.

GIEZEK J.: Zbieg przepisów a konstrukcja przestępstwa ciagłego. W: Zbieg przepisów oraz zbieg przestępstw w polskim prawie karnym. Materiały II Bielańskiego Kolokwium Karnistycznego. Red. J. MAJEwsKI. Torun 2006.

GIEZEK J., KARDAS P.: Zasada ne bis in idem a nowe regulacje ciagłości przestępstwa. „Palestra” 2019, nr 4, s. 7-8.

GrüNWALD G.: Die materielle Rechtskraft im Strafverfahren der Bundesrepublik Deutschland. „Zeitschrift für die gesamte Strafrechtswissenschaft” 1974, Nr. 86.

GRZESZCZYK W.: Wspótpraca z Międzynarodowym Trybunałem Karnym (rozdziat 66 a k.p.k.). „Prokuratura i Prawo” 2005, nr 1.

Hofmański P., Sadzik E., Zgryzek K.: Kodeks Postępowania Karnego. Komentarz do art. 1-296. T. 1. Red. P. HofmańsKi. Warszawa 2011.

Hofmański P., Wróbel A.: Komentarz do art. 6. W: Konwencja o Ochronie Praw Człowieka i Podstawowych Wolności. Komentarz. T. 1. Red. L. GarlicKI. Warszawa 2010.

JAскошsкі M.: Zasada ne bis in idem $w$ orzecznictwie Europejskiego Trybunału Praw Człowieka. „Państwo i Prawo” 2012, nr 9.

JONES J.W.: Law and legal theory of the Greeks. Oxford 1956.

KaFTAL A.: O niektórych zagadnieniach tożsamości przedmiotowej czynu przy przestępstwie ciagłym. „Palestra” 1964, nr 8.

KaFTAL A.: O niektórych zagadnieniach zmiany kwalifikacji czynu na tle orzecznictwa. „Państwo i Prawo” 1962, z. 8-9.

Kaftal A.: Procesowe problemy przestępstwa ciagtego $w$ orzecznictwie Sadu Najwyższego. „Palestra” 1982, z. 1-3.

Kardas P.: Res iudicata a konstrukcja czynu ciagtego. „Czasopismo Prawa Karnego i Nauk Penalnych" 2007, z. 2.

KeMPEN P.H. van, Bemelmans J.: EU protection of substantive criminal law principles of guilt and ne bis in idem under the Charter of Fundamental Rights: Underdevelopment and overdevelopment in an incomplete criminal justice framework. „New Journal of European Criminal Law” 2018, no. 2.

KRAWCZYK P.: Rozważania na temat ciagłości przestępstwa $w$ nawiązaniu do zmian dokonanych $w$ polskim prawie karnym nowelizacja kodeksu karnego $z$ dnia 4 października 2018 roku. „Studenckie Zeszyty Naukowe WPiA UMK” 2019, nr 2 (2). 
MajewsKi J.: „Ten sam czyn” jako jedna z przestanek kumulatywnej kwalifikacji. W: Zbieg przepisów oraz zbieg przestępstw w polskim prawie karnym. Materiały II Bielańskiego Kolokwium Karnistycznego. Red. J. MajEwski, Toruń 2006.

Maunz T. et al.: Grundgesetz-Kommentar. München 1994.

McDermott P.A.: Res judicata and double jeopardy. Butterworths 1999.

PAPIERKOWSKI Z.: Glosa do uchwaty połaczonych Izb Karnej i Wojskowej SN z 8 kwietnia 1966 r., VI KO 42/62. „Państwo i Prawo” 1967, z. 4-5.

Prusak F., Kordik A., ŚWIDA Z.: Prawo karne procesowe. Część ogólna. Red. F. PRUSAK. Wrocław 1995/1996.

ResniK J.: Precluding appeals. „Cornell Law Review” 1942, no. 51.

RodzynKiEwicz M.: Modelowanie pojęć w prawie karnym. Kraków 1998.

Rogalski M.: Przesłanka powagi rzeczy osądzonej $w$ procesie karnym. Kraków 2005.

Rogalski M.: Rzymskie źródła zasady ne bis in idem. „Zeszyty Naukowe Uniwersytetu Rzeszowskiego" 2018, nr 101.

RUDSTEIN D.S.: A brief history of the fifth amendment guarantee against double jeopardy. „William and Mary Bill of Rights Journal” 2005, vol. 14.

RusineK M.: W sprawie uniewinnienia od zarzutu czynu ciagtego - w zwiazku z artykułem P. Kardasa „Res iudicata a konstrukcja czynu ciagłego”. „Czasopismo Prawa Karnego i Nauk Penalnych" 2007, z. 2.

Schabas W.A., El ZeIDy M.M.: Article 17 Issues of admissibility. W: The Rome Statute of the International Criminal Court. A commentary. Eds. O. TRIFFTERER, K. Амвоs. München 2016.

Schmidt-BleibTreu B., Klein F.: Kommentar zum Grundsetz für die Bundesrepublik Deutschland, unter Mitarbeit von Hans Bernhard Brockmeyer. Frankfurt am Main 1990.

SCHROEDER F.C: Die Rechtsnatur des Grundsatzes „ne bis in idem“. „Juristische Schulung" 1997, Nr. 3.

SIGLER J.A.: Double jeopardy: the development of a legal and social policy. Ithaca 1969.

Sigler J.A.: A history of double jeopardy. „The American Journal of Legal History” 1963, vol. 7.

SkorupKa J.: Proces karny. Red. J. SKorupKa. Warszawa 2018.

Tallgren I., Reisinger Coracini A.: Article $20 \mathrm{Ne}$ bis in idem. W: The Rome Statute of the International Criminal Court. A commentary. Eds. O. TrifFTERER, K. Амвоs. München 2016.

Tylman J.: Polskie postępowanie karne. Red. T. GrzegorczyK, J. Tylman. Warszawa 2011.

Waltoś S.: Proces karny. Zarys systemu. Warszawa 2002.

WĄSEK A.: Kodeks karny. Komentarz. T. 1. Gdańsk 1999.

WĄSEK A.: Problemy z przestępstwem ciagtym. W: Prawo karne i proces karny wobec nowych form i technik przestępczości. Red. H.J. Hirsch, P. Hofmański, E.W. PŁywaczewski, C. Roxin. Białystok 1997.

WoJTASzCZYK A., ZonTEK W.: Czy art. 12 k.k. jest ciagtym problemem? „Czasopismo Prawa Karnego i Nauk Penalnych” 2007, z. 2. 


\section{Akty normatywne}

Ustawa z dnia 19 kwietnia 1969 r. Kodeks karny. Dz.U. 1969, nr 13, poz. 94.

Ustawa z dnia 19 kwietnia 1969 r. Kodeks postępowania karnego. Dz.U. 1969, nr 13, poz. 96.

Ustawa z dnia 6 czerwca 1997 r. - Kodeks karny. Dz.U. 1997, nr 88, poz. 553.

Ustawa z dnia 6 czerwca 1997 r. - Kodeks postępowania karnego. Dz.U. 1997, nr 89, poz. 555.

Powszechna Deklaracja Praw Człowieka. Rezolucja Zgromadzenia Ogólnego ONZ 217 A (III) z dnia 10 grudnia 1948 r.

Konwencja o Ochronie Praw Człowieka i Podstawowych Wolności sporządzona w Rzymie dnia 4 listopada 1950 r., zmieniona następnie Protokołami nr 3, 5 i 8 oraz uzupełniona Protokołem nr 2. Dz.U. 1993, nr 61, poz. 284.

Karta praw podstawowych Unii Europejskiej. Dz.U. UE 26.10.2012, C 326/392.

Rzymski Statut Międzynarodowego Trybunału Karnego sporządzony w Rzymie dnia 17 lipca 1998 r. Dz.U. 2003, nr 78, poz. 708.

Rozporządzenie Prezydenta Rzeczypospolitej z dnia 19 marca 1928 r. Kodeks postępowania karnego. Dz.U. 1928, nr 33, poz. 313.

\section{Orzecznictwo}

Uchwała Sądu Najwyższego z dnia 8 kwietnia 1966 r. VI KO 42/62. OSNKW 1966, nr 7, poz. 69.

Uchwała Sądu Najwyższego z dnia 21 listopada 2001 r. I KZP 29/01. OSNKW 2002, nr 1-2, poz. 2, LEX nr 49486.

Uchwała Sądu Najwyższego z dnia 15 czerwca 2007 r. I KZP 15/07. OSNKW 2007, nr 7-8, poz. 55, LEX nr 270947.

Wyrok Europejskiego Trybunału Praw Człowieka z dnia 23 października 1995 r. w sprawie Gradinger v. Austria. Skarga nr 15963/90.

Wyrok Europejskiego Trybunału Praw Człowieka z dnia 30 lipca 1998 r., w sprawie Oliveira v. Szwajcaria. Skarga nr 25711/94.

Wyrok Europejskiego Trybunału Praw Człowieka z dnia 30 maja 2002 r. w sprawie W.F. v. Austria. Skarga nr 38275/97.

Wyrok Europejskiego Trybunału Praw Człowieka z dnia 6 czerwca 2002 r. w sprawie Sailer v. Austria. Skarga nr 38237/97.

Wyrok Europejskiego Trybunału Praw Człowieka z dnia 1 lutego 2007 r. w sprawie Storbråten v. Norwegia. Skarga nr 12277/94.

Wyrok Wielkiej Izby Europejskiego Trybunału Praw Człowieka z dnia 10 lutego 2009 r. w sprawie Zolotuchin v. Rosja. Skarga nr 14939/03.

Wyrok Trybunału Sprawiedliwości Unii Europejskiej (Wielka Izba) z dnia 20 marca 2018 r. w sprawach połączonych C - 596/16 i C - 597/16 Enzo Di Puma oraz Menci.

Wyrok Trybunału Konstytucyjnego z dnia 29 kwietnia 1998 r. K 17/97. OTK 1998, nr 3, poz. 30.

Wyrok Trybunału Konstytucyjnego z dnia 4 września 2007 r. P 43/06. OTK-A 2007, nr 8, poz. 95. 
Wyrok Trybunału Konstytucyjnego z dnia 18 listopada 2010 r. P 29/09. OTK-A 2010, nr 9, poz. 104.

Wyrok Trybunału Konstytucyjnego z dnia 21 października 2015 r. P 32/12. Dz.U. 2015, poz. 1742.

Wyrok Sądu Najwyższego z dnia 24 października 1935 r. I K 675/33. Orzecznictwo Izby Karnej SN 1936, z. VI, poz. 216.

Wyrok Sądu Najwyższego z dnia 9 marca 1970 r. IV KR 50/69. LEX nr 1673710.

Wyrok Sądu Najwyższego z dnia 10 kwietnia 1974 r. V KR 6/74. OSNKW 1974, nr 7-8, poz. 135, LEX nr 18808.

Wyrok Sądu Najwyższego z dnia 12 lutego 1975 r. I KR 226/74. LEX nr 216633.

Wyrok Sądu Najwyższego z dnia 22 stycznia 2014 r. III KK 439/13. LEX nr 1427468.

Wyrok Sądu Najwyższego z dnia 28 sierpnia 2018 r. III KK 389/18. LEX nr 2539905.

Postanowienie Europejskiego Trybunału Praw Człowieka z dnia 14 września 1999 w sprawie Ponsetti i Chesnel v. Francja. Skargi nr 36855/97 i 41731/98.

Postanowienie Sądu Najwyższego z dnia 28 listopada 1931 r. II 1K 431/31, 432/31. Zbiór Orzeczeń Sądu Najwyższego, Orzeczenia Izby Drugiej (Karnej) 1932, z. I, poz. 4.

Postanowienie Sądu Najwyższego z dnia 8 kwietnia 2014 r. IV KK 66/14. OSNKW 2014, nr 10, poz. 75, LEX nr 1494018.

Postanowienie Sądu Apelacyjnego w Katowicach z dnia 20 czerwca 2001 r. II AKo 92/01. OSPriPr 2002, nr 5, poz. 28, LEX nr 53214.

Opinia Rzecznika Generalnego D. Ruliza-Jaraba Colomera przedstawiona w dniu 20 października 2005 r. w sprawie Van Esbroeck, C-436/04.

Opinia Rzecznika Generalnego D. Ruiza-Jaraba Colomera przedstawiona w dniu 8 czerwca 2006 r. w sprawie Van Straaten, C-150/05.

Opinia Rzecznika Generalnego E. Sharpston przedstawiona w dniu 15 czerwca 2006 r. w sprawie Gasparini, C-467/04.

Stanowisko Rzecznika Praw Obywatelskich z dnia 18 listopada 2015 r. II.510.1123.2015.MK.

Zdanie odrębne sędziego B. Replika w sprawie Oliveira v. Szwajcaria. Skarga nr 25711/94. 